\title{
Current status of alert alien species management for the establishment of proactive management systems in Korea
}

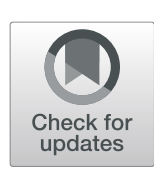

\author{
Seung Hun Son, A-Ram Jo and Dong Eon Kim ${ }^{*}$ (1)
}

\begin{abstract}
Background: Some of the introduced alien species introduced settle, multiply, and spread to become invasive alien species (IAS) that threaten biodiversity. To prevent this, Korea and other countries legally designate and manage alien species that pose a risk to the environment. Moreover, 2160 alien species have been introduced in South Korea, of which 1826 animals and 334 plants are designated. The inflow of IAS can have negative effects such as ecosystem disturbance, habitat destruction, economic damage, and health damage to humans. To prevent damage caused by the inflow of IAS in advance, species that could potentially pose a risk to the environment if introduced in South Korea were designated as alert alien species (AAS).

Results: The designation criteria were in accordance with the "Act on the Conservation and Use of Biological Diversity" and the "Regulations on the Ecological Risk Assessment of AAS and IAS" by the National Institute of Ecology. The analysis result of risk and damage cases indicated that mammals affect predation, competition, human economic activity, virus infection, and parasite infection. Birds have been demonstrated to affect predation, competition, human economic activity, and health. It was indicated that plants intrude on the ecosystem by competing with native species with their high-population density and capacity to multiply and cause allergic inducement. Interestingly, 300 species, including 25 mammals, 7 birds, 84 fishes, 28 amphibians, 22 reptiles, 1 insect, 32 spiders, 1 mollusk, 1 arthropod, and 99 plants, are included in the list of AAS.

Conclusions: AAS designation plays a role in preventing the reduction of biodiversity by IAS in South Korea and preserving native species. Moreover, it is determined to provide considerable economic benefits by preventing socio-economic losses and ecological damage.
\end{abstract}

Keywords: Alert alien species, Biodiversity, Conservation, Invasive alien species, Risk assessment

\section{Introduction}

Alien species are introduced either intentionally or unintentionally around the world by human activities. Human activities have escalated due to the vitalization of overseas travel based on the increase in trade and transportation development between countries, etc., and this led to the increased spread of alien species (SCBD, 2014). The inflow of alien species in natural and semi-natural ecosystems has a negative effect on

* Correspondence: eco0106@nie.re.kr

Invasive Alien Species Research Team, Division of Ecological Safety, Bureau of Survey and Safety, National Institute of Ecology, Seocheon 33657, Korea the economy and social facilities (Bomford, 2008). Such influence will gradually accelerate, and the inflow of alien species will increase up to 20 times in 30 years, thus increasing the damage (Sardain et al., 2019). Furthermore, environmental problems caused by the indiscriminate use of resources by humans affect habitat fragmentation and climate change. These environmental problems disturb the ecosystem and affect the settlement and multiplication of alien species when they enter the native ecosystem (Sharp et al., 2011). The inflow of invasive alien species (IAS) makes the ecosystem more vulnerable and

(c) The Author(s). 2021 Open Access This article is licensed under a Creative Commons Attribution 4.0 International License, which permits use, sharing, adaptation, distribution and reproduction in any medium or format, as long as you give appropriate credit to the original author(s) and the source, provide a link to the Creative Commons licence, and indicate if changes were made. The images or other third party material in this article are included in the article's Creative Commons licence, unless indicated otherwise in a credit line to the material. If material is not included in the article's Creative Commons licence and your intended use is not permitted by statutory regulation or exceeds the permitted use, you will need to obtain permission directly from the copyright holder. To view a copy of this licence, visit http://creativecommons.org/licenses/by/4.0/. 
unhealthy, leading to a reduction of biodiversity (IUCN, 2000).

Although the damage caused by IAS among the developed and developing countries differs, all the countries signed the Convention on Biological Diversity to enhance the understanding of biodiversity due to the importance of public awareness in the matter. Moreover, Aichi Biodiversity Targets were selected for global biodiversity conservation from 2011 to 2020 (Junior et al., 2018). The management of alien species is one of the 20 detailed targets. It was reported that inflow pathways should be identified, and alien species that flow in shall be managed and controlled to prevent the inflow and settlement of alien species (SCBD, 2014). For this purpose, the International Union for Conservation of Nature (IUCN), an international organization, has published a list of representative IAS. However, it is difficult to manage the inflow of all alien species around the world through an international cooperation organization. Therefore, a list of alien species has been designated and managed on the national level by assessing the impact of alien species on the ecosystem or selecting the species that threaten the ecosystem (Koh et al., 2002; CalIPC., 2006; Gederaas et al., 2012).

In 2005, Japan began to designate IAS with the introduction of the "Invasive Alien Species Act (IAS Act)." In 2019, 145 species were designated as IAS, whereas others were designated and managed as Uncategorized Alien Species (UAS) or Living Organisms Required to have a Certificate Attached (LORCA) by their types (Kil et al., 2015). China manages 734 species through the "Chinese Biodiversity Conservation Action Plan" (Xu et al., 2012). The UK enacted the "Wildlife and Countryside Act" in 1981 to prevent the inflow of IAS. The "Great Britain Invasive Non-Native Species Strategy (GBNNSS)" was established in 2013 based on the "Strategy for Controlling Invasive Species" developed by Great Britain Non-Native Species Secretariat in 2008. Based on this, 142 species are legally prohibited from entering the UK (GBNNSS, 2016). The damage inflicted upon indigenous species by alien species is more critical in New Zealand compared with the continent as it comprises many islands. Therefore, New Zealand has been blocking the inflow of alien species as a precautionary measure (Department of Conservation, 1996; Brenton-Rule et al., 2016). Furthermore, the Biosecurity Act enacted in 1993 defines unwanted organisms to prevent the inflow of 969 species that are not on the Clean List (Ministry for primary industries n.d., 2016). The USA manages alien species with Clean List and Dirty List. In particular, the Dirty List prevents the inflow of alien species under the Lacey Act and the Federal Noxious Weed Act (Congress U. S., 1993) and promotes integrated management of 2873 species designated by each state (US department of agriculture, 2010). The IUCN has announced 100 of the world's worst IAS as targets for global management. Europe designated 503 species, NOBANIS designated 496 species, and Australia designated 563 species as IAS to prevent and manage the inflow by law (Table 1). Furthermore, 1109 alien species introduced in South Korea in 2011 doubled to 2160 in 2013 (Kil and Kim, 2014). IAS comprises various classifications, including mammals, birds, fish, amphibians, reptiles, insects, plants, and invertebrates (Ministry of Environment notification, 2017). The designation and management of alert alien species (AAS) were added to the Act on the Conservation and the Use of Biological diversity in 2019 to prevent the increasing inflow of alien species and reduce the damage caused by it. AAS are alien species that may cause disruption in the native ecosystem if introduced, and 300 species have been designated and announced currently.

This study introduces the status of laws and designations of IAS in Korea and highlights the "Act on the Conservation and the Use of Biological Diversity," which manages AAS. We focused on analysis on (1) criteria of designating AAS and (2) impact of AAS on the ecosystem, socio-economy, and human health.

\section{Material and methods}

\section{The Act on the Conservation and the Use of Biological Diversity of South Korea}

The Act on the Conservation and the Use of Biological Diversity was first enacted in 2013 and amended in 2019. Article 2 (Definition) defines alien species as organisms that exist outside their place of origin or habitat after being artificially or naturally introduced from foreign countries. In addition, AAS is defined as a species, among alien species, that disturb or are likely to disturb the balance of the ecosystem. AAS are designated and managed under risk evaluation (Article 21-2), approval for Importation and Inbound transfer of Species of concern for Domestic Inflow (Article 22), and management of Species of Concern for Domestic Inflow (Article 22-2).

\section{Procedure of designations related to Alien Species in South Korea}

AAS are species that are judged to be harmful when alien species are introduced into the domestic ecosystem. To designate AAS, a list of alien species was made that have not been introduced into Korea. Alien species data was collected by ecological 
Table 1 Status of invasive alien species to be prevented and managed by law

\begin{tabular}{|c|c|c|c|c|c|c|c|c|c|}
\hline & IUCN & Japan & China & EU & NOBANIS & UK & Australia & New Zealand & USA \\
\hline Mammals & 14 & 25 & 10 & 43 & 26 & 7 & 75 & 52 & 29 \\
\hline Birds & 8 & 24 & 35 & 45 & 46 & 35 & 8 & 15 & 119 \\
\hline Fishes & 3 & 7 & 8 & 43 & 13 & 12 & 53 & 35 & 33 \\
\hline Amphibian & 3 & 21 & 5 & 12 & 5 & 5 & 4 & 19 & 31 \\
\hline Reptile & 2 & 14 & 3 & 18 & 9 & 2 & 12 & 3 & 69 \\
\hline Insect & 17 & 21 & 252 & 15 & 102 & 30 & 4 & 133 & 489 \\
\hline Spider & 0 & 7 & 0 & 0 & 0 & 0 & 0 & 6 & 0 \\
\hline Mollusca & 4 & 4 & 25 & 36 & 22 & 3 & 0 & 37 & 31 \\
\hline Arthropod & 3 & 5 & 16 & 21 & 46 & 7 & 0 & 11 & 25 \\
\hline Plant & 37 & 16 & 337 & 264 & 113 & 28 & 407 & 658 & 2047 \\
\hline Others & 9 & 1 & 63 & 6 & 114 & 13 & 0 & 0 & 4 \\
\hline Total & 100 & 145 & 734 & 503 & 496 & 142 & 563 & 969 & 2877 \\
\hline
\end{tabular}

characteristics, physiological characteristics, and harmful cases on the ecosystem, socio-economy, and human health. The committee evaluated the data collected according to AAS designation criteria. The AAS designation criteria are divided into four categories and the specific details (Table 2).

\section{Results}

\section{Status of AAS designation}

Three hundred species are designated and announced as AAS in South Korea. These include 25 mammals, 7 birds, 84 fish, 28 amphibians, 22 reptiles, 1 insect, 99 plants, and 34 invertebrates. Moreover, 15 species from the World's Worst 100 IAS by IUCN are included, which comprises 4 mammals (Herpestes auropunctatus, Herpestes javanicus, Sciurus carolinensis, and Mustela erminea), 2 fish (Gambusia affinis and Lates niloticus), 1 amphibian (Rhinella(=Bufo) marinus), 1 reptile (Boiga irregularis), 1 invertebrate (Anoplolepis gracilipes), and 6 plants (Chromolaena odorata, Mikania micrantha, Sphagneticola trilobata, Prosopis glandulosa, Acacia mearnsii, and Ardisia elliptica). Furthermore, 238 of the 300 AAS were indicated as species for legal management by foreign countries (Appendix 1).

\section{Origin of AAS regional distribution}

Nine regions were marked as the origin of 300 AAS using the world geographic scheme for recording plant distributions. The nine regions are Europe, Africa, AsiaTemperate, Asia-tropical, Australasia, Pacific, Northern America, Southern America, and Antarctic (Brummitt, 2001). The Asia-Temperate region reported for the largest proportion of the 300 species designated as AAS with $28 \%$, followed by Europe with $17 \%$ and North America with 16\%. Africa and South America were 12\% each and Asia-tropical was $8 \%$ (Fig. 1).

Table 2 Four categories and their specific details for designating AAS in South Korea

$\mathbf{4}$ criteria of designating AAS

Species that have caused social or ecological damage

Species with genetic and ecological characteristics similar to existing IAS (30 species)

Species with a high probability of settlement due to habitat conditions being similar to those in South Korea

\section{Specific details}

Promotion of the designation of species recognized as harmful by international organizations such as IUCN's World's Worst IAS comprising 100 species

Specify species for legal management by neighboring countries (such as China and Japan) and major trading partners (such as US and EU); prior review of species prohibited to import from other countries

Promotion of the designation of species that caused social damage such as human diseases and industrial damage

Promotion of the designation of species that caused ecological harm through predation, hybridization, etc., of indigenous species

Promotion of the IAS designation of similar species expected to have increased demand due to the ballooning effects of IAS designation

Promotion of the designation of a genus if there are several allied species with similar attributes

Promotion of the prioritized designation of species that are highly likely to spread due to their high fertility rate 


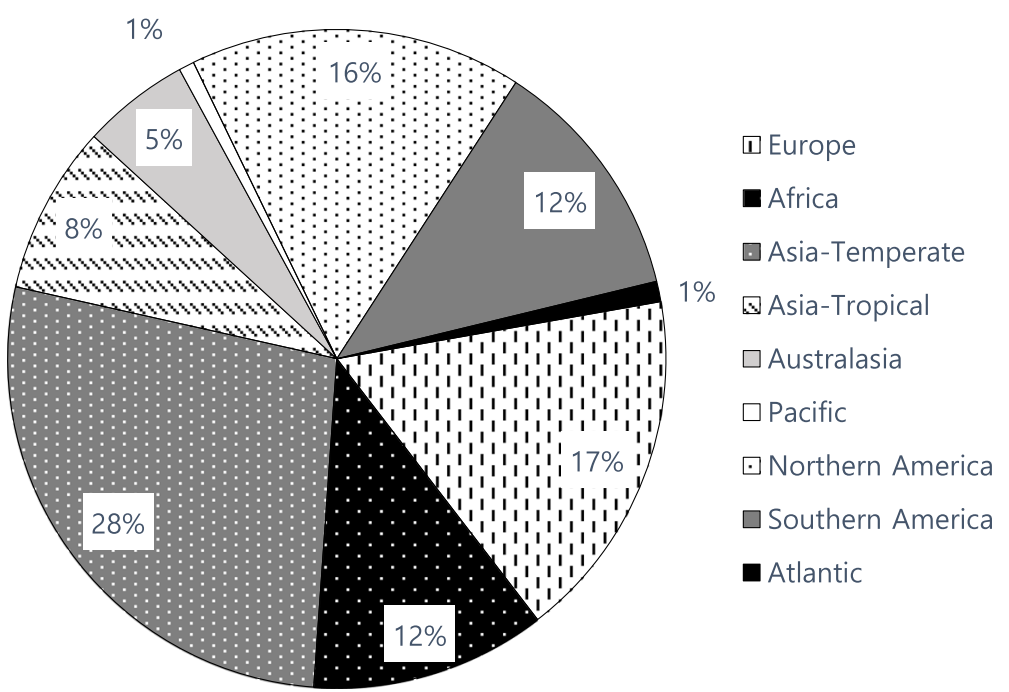

Fig. 1 Ratio of alert alien species' origins

\section{Analysis of AAS effect}

The experts of each classification group assessed AAS in accordance with the "Ecological Risk Assessment of Invasive Alien Species and Designation of Alert Alien Species" from 2013 to 2019. The assessment was determined by combining scores and opinions on the impact of each species on the ecosystem, socio-economy, and human health. Species designated as AAS by the assessment were analyzed for their influence in each classification. The 5 categories of biodiversity, ecosystem function, invasiveness, human health, and human well-being were classified into detailed items. Biodiversity was classified into predation/competition, hybridization, disease transmission, and toxicity/disease. Ecosystem function was classified into nutrient cycle change, physical modification of habitat, disruption of ecosystem structure, destruction of important and/or protected habitat, and the increasing possibility of fire. Invasiveness was classified into high-population density, adaptability, easy spread, possibility of introduction, and difficulty of control, etc. Human health was classified into disease transmission and poisoning/toxicity/injury. Human well-being comprises nuisance and economic loss (Table 3). Among the five categories, mammals appear to have considerable influence on biodiversity and human well-being. In biodiversity, it was analyzed to have an influence on the relations of disease and prediction/competition. Moreover, it had a strong impact on economic loss for human well-being (Fig. 2). It is believed that mammals adversely affect social and economic activities because they are prone to disease and spread diseases as a medium for zoonosis. Birds appear to have considerable influence on biodiversity, human well-being, and invasiveness, which affect prediction/competition in biodiversity. Human well-being affects economic loss. Invasiveness was analyzed to affect high-population

Table 3 Effect of alert alien species on five categories and specific impacts

\begin{tabular}{|c|c|c|c|c|c|}
\hline & \multicolumn{5}{|c|}{ Category impacts } \\
\hline & Biodiversity & Ecosystem function & Invasiveness & Human health & Human wellbeing \\
\hline \multirow[t]{5}{*}{ Specific impacts } & Predation/Competition & Nutrient cycle change & High population density & Disease transmission & Nuisance \\
\hline & Hybridization & $\begin{array}{l}\text { Physical modification of the } \\
\text { habitat }\end{array}$ & Adaptation & $\begin{array}{l}\text { Poisoning/Toxicity/ } \\
\text { Injury }\end{array}$ & Economic loss \\
\hline & Disease transmission & $\begin{array}{l}\text { Disruption of ecosystem } \\
\text { structure }\end{array}$ & Easily spreading & & \\
\hline & Toxicity/Disease & $\begin{array}{l}\text { Destruction of important, } \\
\text { protected habitat }\end{array}$ & Possibility of introduction & & \\
\hline & & Increasing possibility of fire & Difficulty of control & & \\
\hline
\end{tabular}




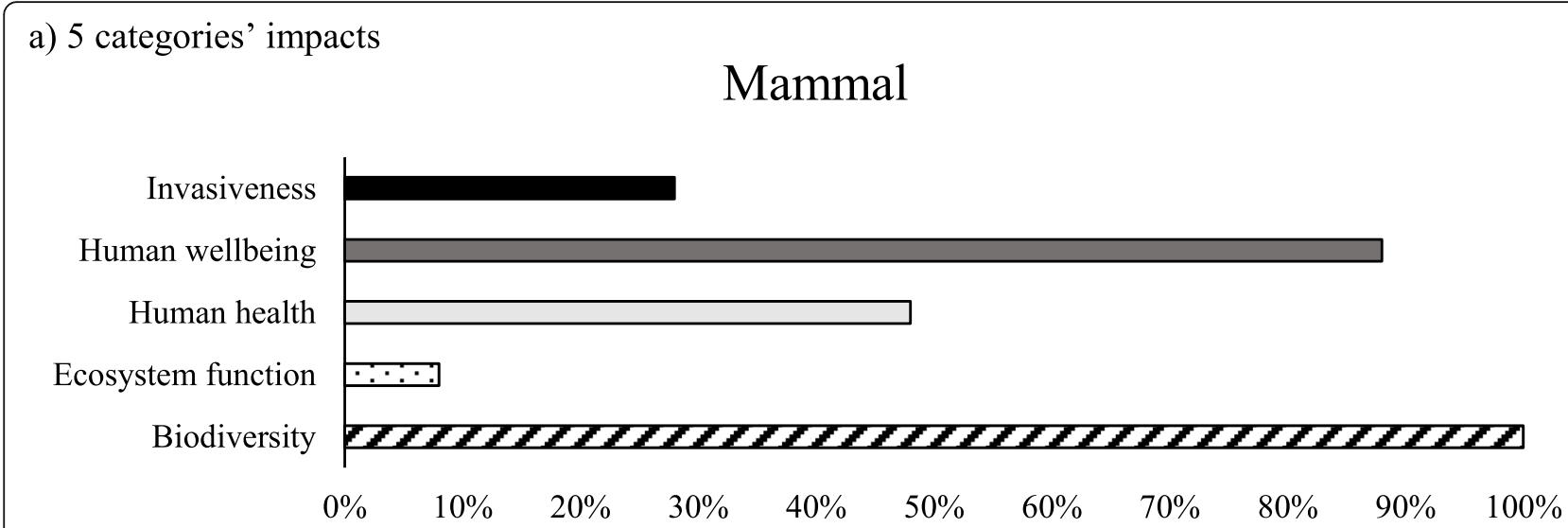

b) Specific impacts of biodiversity

\section{Mammal}

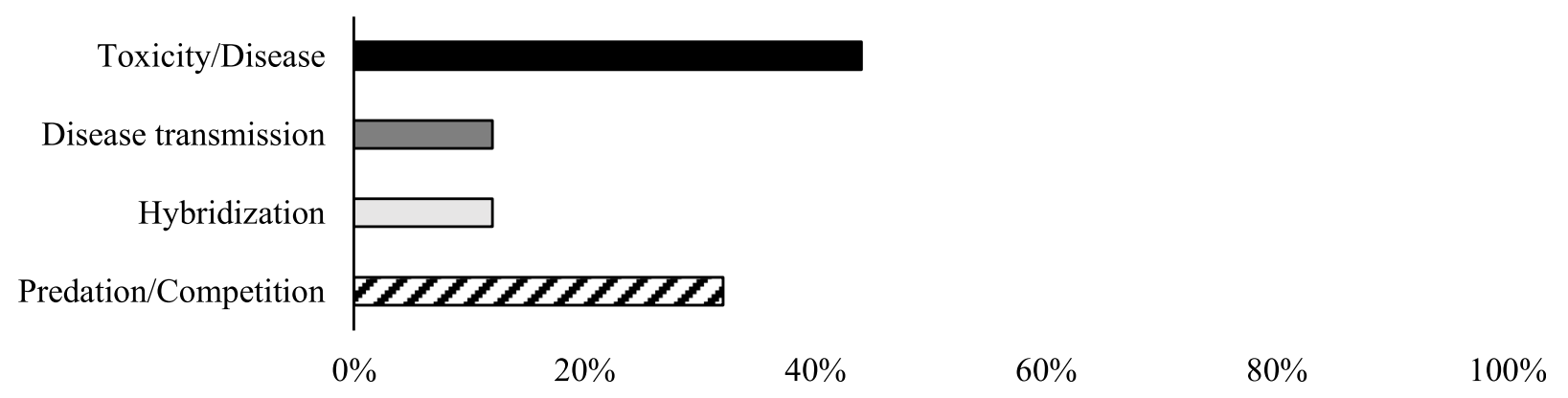

c) Specific impacts of human wellbeing

\section{Mammal}

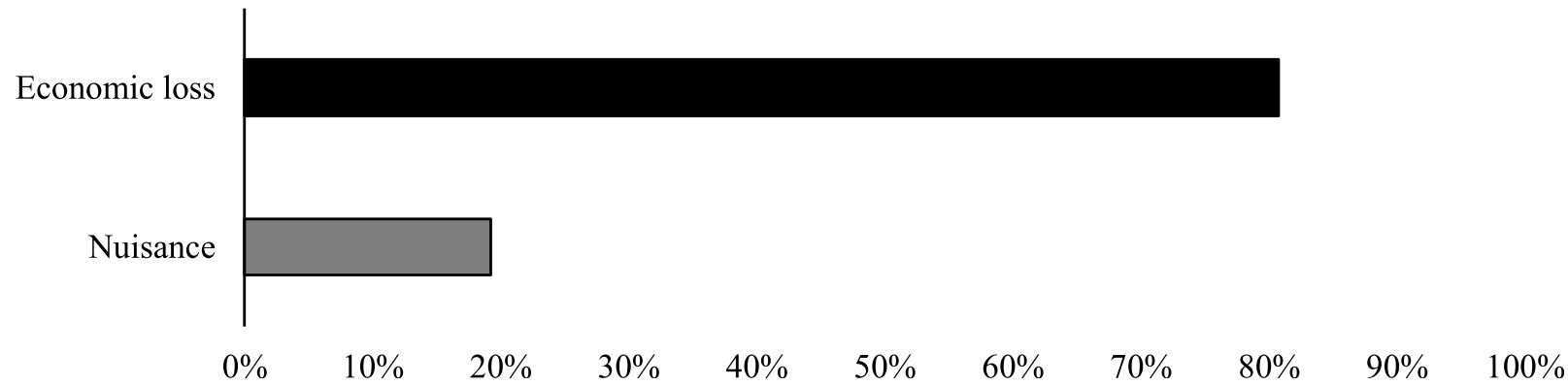

Fig. 2 Ratio of mammal species with specific impacts. a Since the effects of alien species are diverse, the categories affected by each alien species were calculated cumulatively. b, c The specific impact on the categories that have been greatly affected by alien species is calculated as a percentage

density and easy spread (Fig. 3). Efforts and expenses are required to control the inflow of birds due to their high proliferation and ability to easily spread infectious diseases. Fish and reptiles had considerable influence on biodiversity. In the detailed items of biodiversity, fish were explained to affect predation/ competition, hybridization, and toxicity/disease. Reptiles were reported to have a significant impact on the relations of predation/competition (Figs. 4 and 5). It has been found that the inflow of fish causes 
a) 5 categories' impacts

\section{Bird}

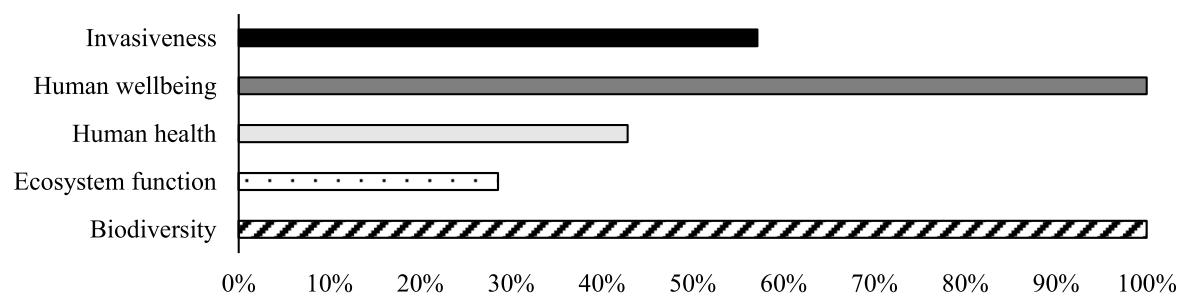

b) Specific impacts of biodiversity

Bird

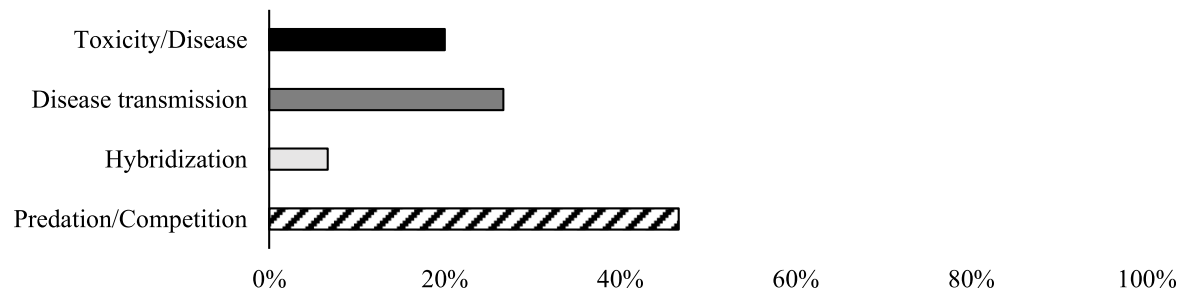

c) Specific impacts of human wellbeing

Bird

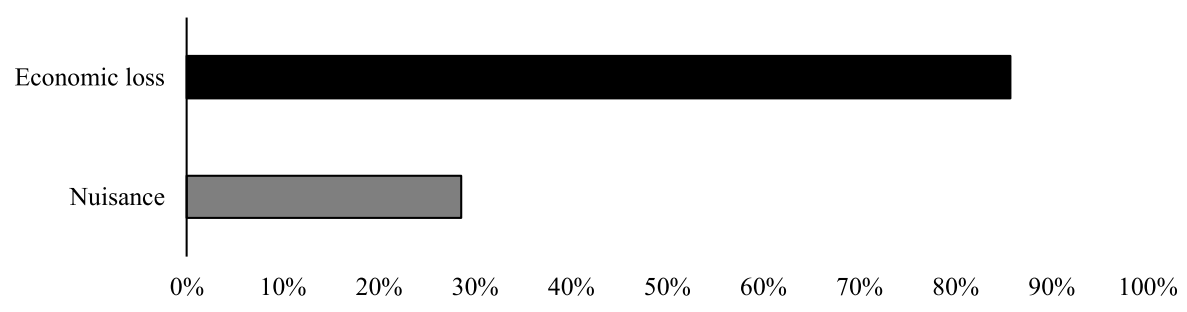

d) Specific impacts of invasiveness

\section{Bird}

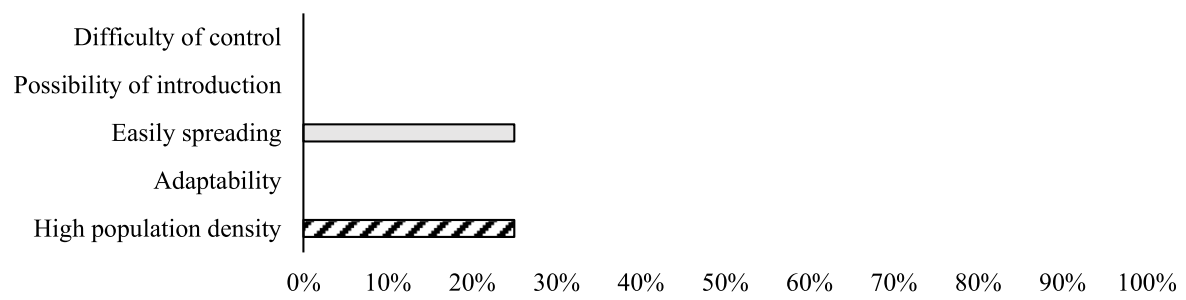

Fig. 3 Ratio of bird species with specific impacts. a Since the effects of alien species are diverse, the categories affected by each alien species were calculated cumulatively. $\mathbf{b}, \mathbf{c}, \mathbf{d}$ The specific impact on the categories that have been greatly affected by alien species is calculated as a percentage

hybridization with native species and damage, leading to the reduction of native species and biodiversity. Amphibians have been demonstrated to have a considerable impact on biodiversity and invasiveness. They were analyzed to considerably impact predation/competition in biodiversity and on easy spread and adaptability in invasiveness (Fig. 6). Plants were reported to have considerable influence on biodiversity. It was analyzed to have a strong effect on invasiveness compared with other 


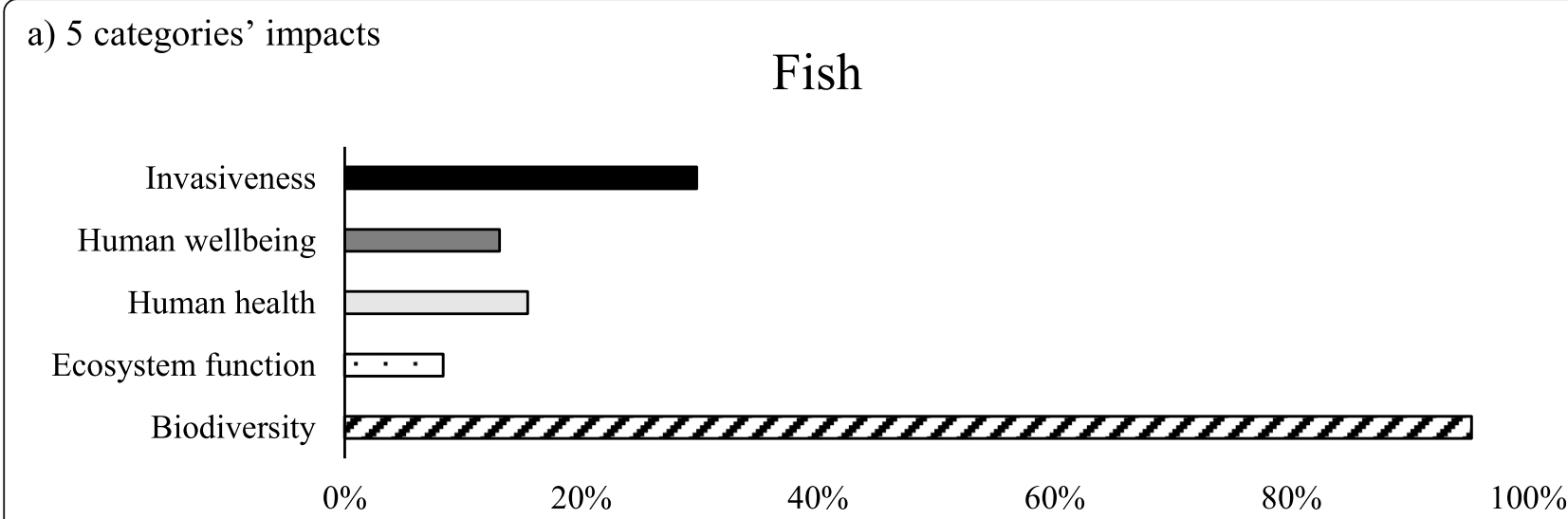

b) Specific impacts of biodiversity

Fish

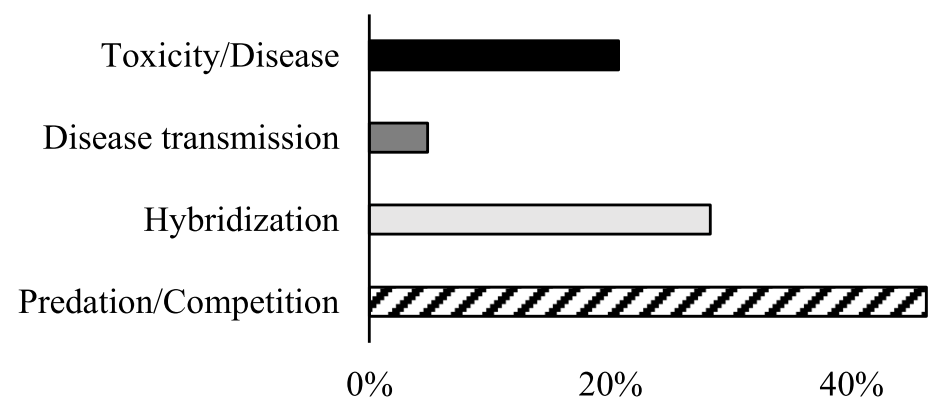

Fig. 4 Ratio of fish species with specific impacts. a Since the effects of alien species are diverse, the categories affected by each alien species were calculated cumulatively. $\mathbf{b}$ The specific impact on the categories that have been greatly affected by alien species is calculated as a percentage

classifications and on human well-being. In biodiversity, plants have been demonstrated to affect predation/competition and toxicity/disease. They affected high-population density and easy spread of invasiveness and economic loss in human well-being (Fig. 7). When plants are flowed in, they form flora and rapidly spread to compete with native species. It is known that alien plants that win against native plants destroy the habitat environment and affect other species living in their habitats. All classifications were identified to influence the relations of predation/competition in the biodiversity category. Predation affects the population sizes of alien and native species, and competition is caused due to the utilization of resources such as habitat and food.

\section{Discussion}

If alien species are flowed in, multiply, and settle, expenses and effort are required for control and management. Luque (2014) reported that the total cost borne by each country to effectively prevent the inflow of alien species from around the world is $>\$ 300$ billion per year. In Australia, the European fox (Vulpes vulpes) has affected native plants, thus causing damage amounting to $\sim \$ 190$ million a year (McLeod, 2004). The European carp (Cyprinus carpio) affected the ecosystem, thus reducing the biodiversity of native fish, plants, and invertebrates; the damage amount was reported to be $\sim \$ 11.8$ million a year (McLeod, 2004). It is reported that the damage in EU was $\sim € 12$ billion a year (European Commission, 2014; Kettunen et al., 2008), that in the USA was $\$ 8.7$ billion from 2010 to 2013, and that in Japan was $>¥ 1$ billion from 2007 to 2012 (Ministry of Environment, 2014). To efficiently reduce the cost of preventing and managing alien species, it is necessary to designate AAS and block the species in advance. Moreover, the inclusion of AAS in the quarantine system for export and import trade goods at airports and ports will strictly prevent the inflow of AAS. Moreover, if relevant ministries cooperate to preemptively prevent AAS from the customs' entry in the face of a steady increase in the inflow of alien species into the country, it is believed to effectively reduce control 


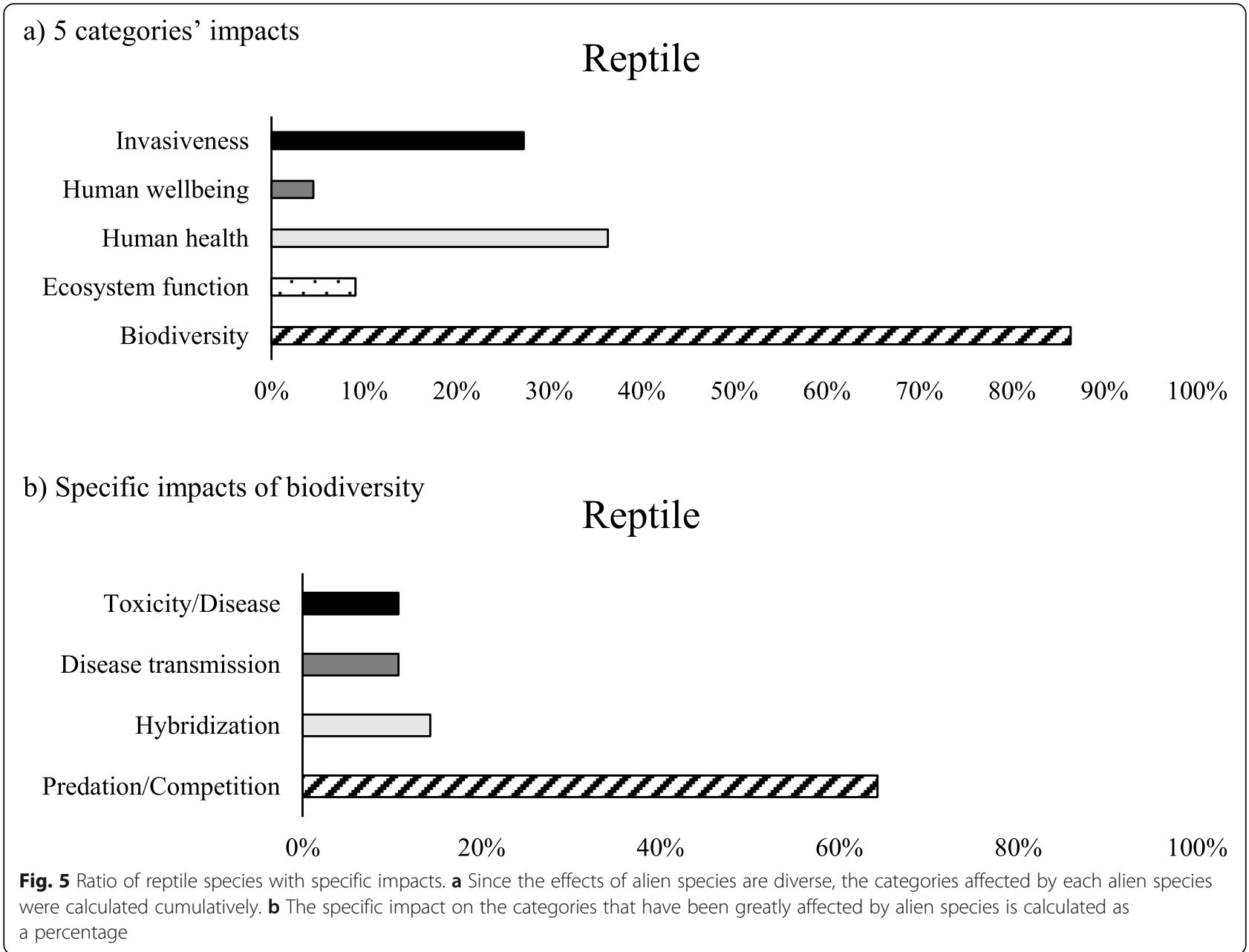

and management costs related to alien species. By comparing the origin and distribution status of AAS with the foreign trade bureau (import), the government can draw up a list of countries that require more thorough quarantine during the importing process. This is believed to rigorously prevent the inflow of AAS. In South Korea, AAS has been designated and officially announced since 2019 with the revision of the Act on the Conservation and the Use of Biological Diversity. To add and facilitate the list of AAS in the future, the AAS designation process needs to be more systematized. In particular, to enhance the system for preventing alien species, the pathway of alien species should be identified to block the intentional inflow and reduce the unintentional inflow. Furthermore, it is important to identify species that can adapt to the current climate zone. Since habitable species easily settle and multiply if they flow in, the process of collecting information on characteristics of alien species by climate group shall be strengthened.

\section{Conclusion}

This study was conducted to analyze the effects of AAS on the environment, economy, and human. The designation of AAS has an influence on preventing the reduction of biodiversity and preserving native species. In addition, it provided considerable economic benefits by preventing socio-economic losses and ecological damage. However, the AAS assessment system currently used in South Korea is slightly different from the revised law. Hence, the assessment system shall be supplemented in accordance with the law by assessing the AAS that have been enlisted to date. It seems necessary to supplement the AAS assessment system with a scientific and systematic assessment system by actively accepting various foreign assessment systems such as AquaNIS, EFSA, ENSARS, EPPO, FISK, GABLIS, GB NNRA, GISS, EICAT, and NORWAY SCHEME. Furthermore, to prevent damage by IAS that have been identified globally, a system should be placed into practice to prevent the inflow of suspected species by broadly designating AAS as a precautionary measure and aim for early detection. 
a) 5 categories' impacts

\section{Amphibian}

Invasiveness

Human wellbeing

Human health

Ecosystem function

Biodiversity

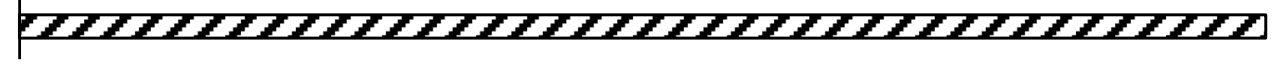

$\begin{array}{lllllllllll}0 \% & 10 \% & 20 \% & 30 \% & 40 \% & 50 \% & 60 \% & 70 \% & 80 \% & 90 \% & 100 \%\end{array}$

b) Specific impacts of biodiversity

\section{Amphibian}

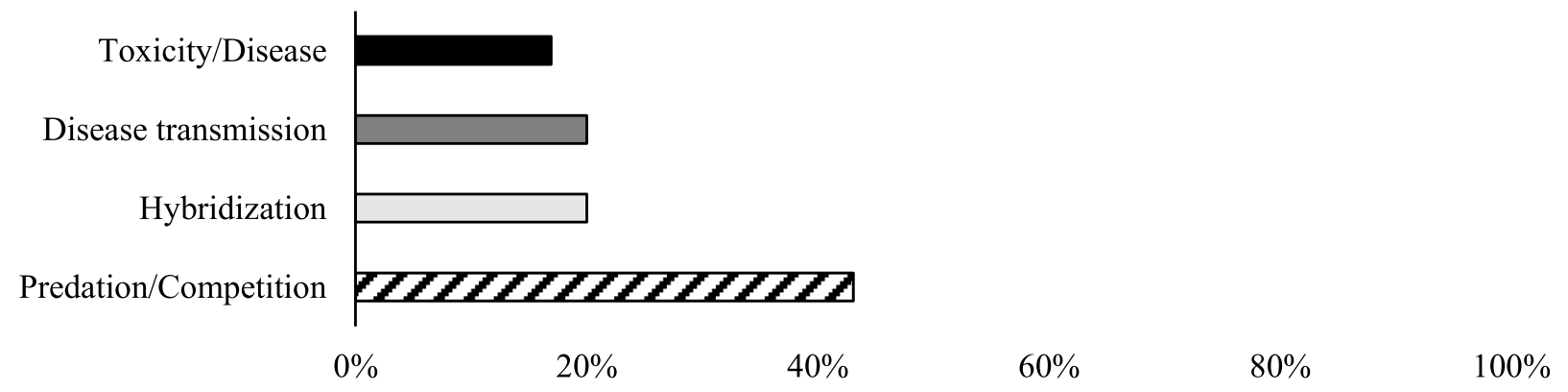

c) Specific impacts of invasiveness

\section{Amphibian}

Difficulty of control

Possibility of introduction

Easily spreading

Adaptability

High population density

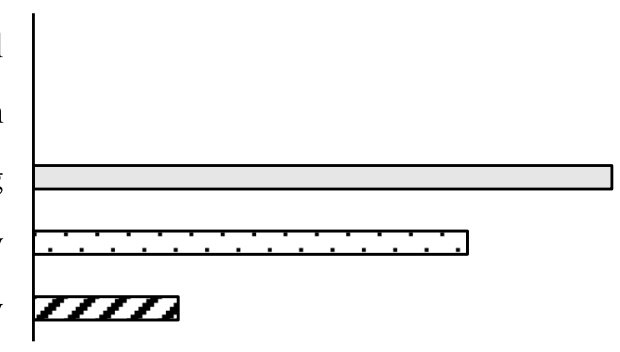

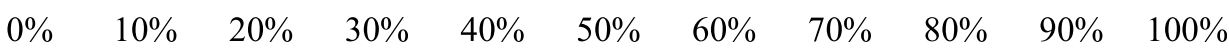

Fig. 6 Ratio of amphibian species with specific impacts. a Since the effects of alien species are diverse, the categories affected by each alien species were calculated cumulatively. $\mathbf{b}, \mathbf{c}$ The specific impact on the categories that have been greatly affected by alien species is calculated as a percentage 
a) 5 categories' impacts

\section{Plant}

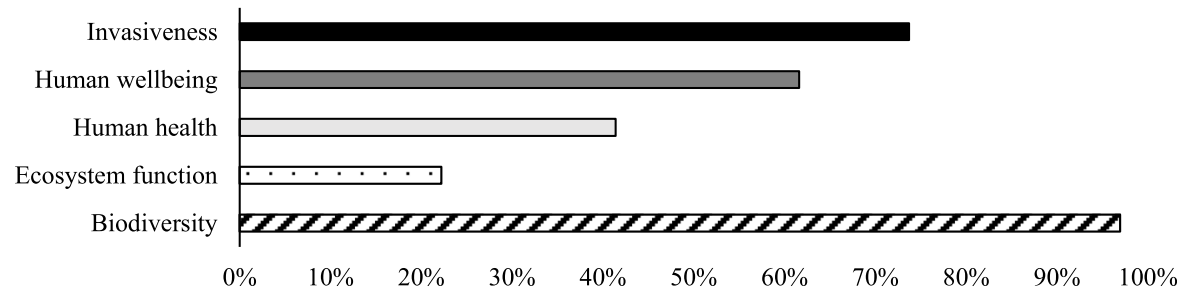

b) Specific impacts of biodiversity

\section{Plant}

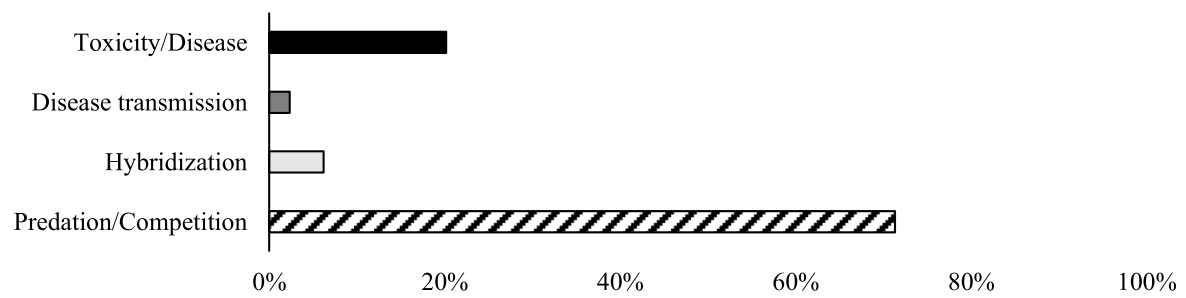

c) Specific impacts of human wellbeing

\section{Plant}

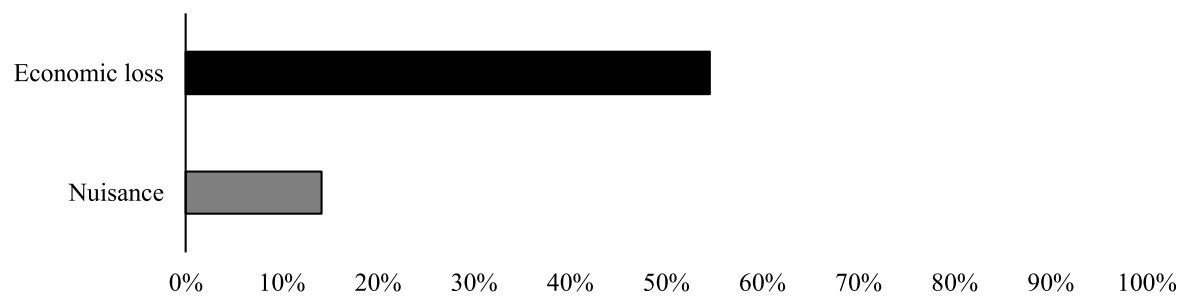

d) Specific impacts of invasiveness

\section{Plant}

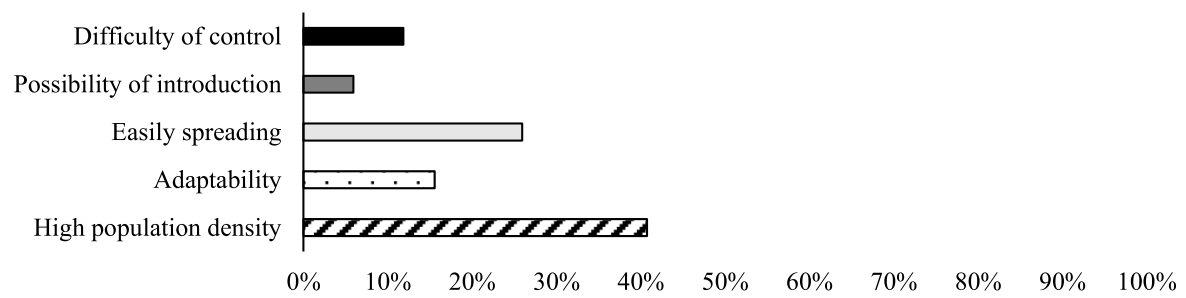

Fig. 7 Ratio of plant species with specific impacts. a Since the effects of alien species are diverse, the categories affected by each alien species were calculated cumulatively. $\mathbf{b}, \mathbf{c}, \mathbf{d}$ The specific impact on the categories that have been greatly affected by alien species is calculated as a percentage 


\section{Appendix 1}

Table 4 List of alert alien species in Republic of Korea

\begin{tabular}{|c|c|c|c|}
\hline No. & Group & Scientific name & Listed in \\
\hline 1 & Mammal & Rattus exulans & Australia \\
\hline 2 & & Peromyscus maniculatus & \\
\hline 3 & & Callosciurus finlaysonii & Japan, Europe \\
\hline 4 & & Herpestes auropunctatus & IUCN, Japan \\
\hline 5 & & Sciurus aureogaster & Japan, USA \\
\hline 6 & & Glis glis & UK \\
\hline 7 & & Castor fiber & \\
\hline 8 & & Odocoileus virginianus & New Zealand \\
\hline 9 & & Sus scrofa vittatus & Europe \\
\hline 10 & & Lepus californicus & USA \\
\hline 11 & & Herpestes javanicus & IUCN, Japan, Europe \\
\hline 12 & & Sciurus carolinensis & IUCN, Japan, Europe \\
\hline 13 & & Mustela erminea & IUCN, New Zealand \\
\hline 14 & & Dasypus novemcinctus & \\
\hline 15 & & Mustela vison & Japan, Europe, UK \\
\hline 16 & & Atelerix albiventris & Japan \\
\hline 17 & & Chlorocebus aethiops & \\
\hline 18 & & Dasyprocta leporina & USA \\
\hline 19 & & Desmodus rotundus & \\
\hline 20 & & Eliomys quercinus & \\
\hline 21 & & Epomops franqueti & \\
\hline 22 & & Hypsignathus monstrosus & \\
\hline 23 & & Ovis orientalis & \\
\hline 24 & & Puma yagouaroundi & USA \\
\hline 25 & & Callosciurus erythraeus & Japan, Europe \\
\hline 26 & Bird & Acridotheres tristis & IUCN, USA, Australia, New Zealand, Europe \\
\hline 27 & & Passer domesticus & Australia, New Zealand, USA \\
\hline 28 & & Phasianus versicolor & \\
\hline 29 & & Pycnonotus jocosus & Japan, Australia, USA \\
\hline 30 & & Streptopelia chinensis & Australia \\
\hline 31 & & Carpodacus mexicanus & USA \\
\hline 32 & & Corvus splendens & Europe, UK, Australia, USA \\
\hline 33 & Fish & Micropterus dolomieu & Japan \\
\hline 34 & & Siniperca chuatsi & Japan \\
\hline 35 & & Gambusia affinis & IUCN, Japan, China, Europe, New Zealand, USA \\
\hline 36 & & Esox lucius & Japan \\
\hline 37 & & Channa striata & USA \\
\hline 38 & & Neogobius melanostomus & Japan, Europe, USA \\
\hline 39 & & Perca fluviatilis & Japan, China, New Zealand, USA \\
\hline 40 & & Clarias gariepinus & China, Europe \\
\hline 41 & & Piaractus brachypomus & China, USA \\
\hline 42 & & Pygocentrus nattereri & China, USA \\
\hline 43 & & Atractosteus spatula & Japan \\
\hline
\end{tabular}


Table 4 List of alert alien species in Republic of Korea (Continued)

\begin{tabular}{|c|c|c|c|}
\hline No. & Group & Scientific name & Listed in \\
\hline 44 & & Phractocephalus hemioliopterus & \\
\hline 45 & & Maccullochella peelii & Japan \\
\hline 46 & & Alosa sapidissima & \\
\hline 47 & & Alosa pseudoharengus & USA \\
\hline 48 & & Amia calva & USA \\
\hline 49 & & Sander lucioperca & Japan, Europe, USA \\
\hline 50 & & Ictiobus cyprinellus & China \\
\hline 51 & & Ictiobus niger & Europe \\
\hline 52 & & Labeo rohita & China \\
\hline 53 & & Lepomis cyanellus & Japan, USA \\
\hline 54 & & Lepomis megalotis & Japan \\
\hline 55 & & Micropterus punctulatus & Japan, USA \\
\hline 56 & & Misgurnus fossilis & \\
\hline 57 & & Mylopharyngodon piceus & China \\
\hline 58 & & Paramisgurnus dabryanus & \\
\hline 59 & & Perccottus glenii & Europe, USA \\
\hline 60 & & Petromyzon marinus & \\
\hline 61 & & Pylodictis olivaris & Japan, Europe, USA \\
\hline 62 & & Salmo salar & China, Europe \\
\hline 63 & & Silurus glanis & Japan, USA \\
\hline 64 & & Ameiurus nebulosus & Japan, Europe, New Zealand \\
\hline 65 & & Ameiurus melas & Japan, Europe \\
\hline 66 & & Morone americana & Japan, USA \\
\hline 67 & & Morone chrysops & Japan, USA \\
\hline 68 & & Scardinius erythrophthalmus & New Zealand, USA \\
\hline 69 & & Acheilognathus tabira erythropterus & Japan \\
\hline 70 & & Aspius aspius & \\
\hline 71 & & Biwia zezera & \\
\hline 72 & & Gnathopogon elongatus elongatus & \\
\hline 73 & & Ischikauia steenackeri & \\
\hline 74 & & Ictiobus bubalus & \\
\hline 75 & & Esox niger & Japan \\
\hline 76 & & Gasterosteus microcephalus & \\
\hline 77 & & Oncorhynchus masou rhodurus & \\
\hline 78 & & Oncorhynchus clarkii & \\
\hline 79 & & Catostomus Catostomus & \\
\hline 80 & & Cobitis biwae & \\
\hline 81 & & Acheilognathus asmussii & Japan \\
\hline 82 & & Carassius gibelio & USA \\
\hline 83 & & Squalius cephalus & \\
\hline 84 & & Leuciscus leuciscus & \\
\hline 85 & & Sarcocheilichthys variegatus microoculus & \\
\hline 86 & & Lepomis humilis & Japan, USA \\
\hline 87 & & Channa panaw & \\
\hline
\end{tabular}


Table 4 List of alert alien species in Republic of Korea (Continued)

\begin{tabular}{|c|c|c|c|}
\hline No. & Group & Scientific name & Listed in \\
\hline 88 & & Sander volgensis & Japan \\
\hline 89 & & Liobagrus reini & \\
\hline 90 & & Lates niloticus & IUCN, Japan, USA \\
\hline 91 & & Morone saxatilis & Japan, China \\
\hline 92 & & Gymnocephalus cernua & Japan, USA \\
\hline 93 & & Leuciscus idus & New Zealand, USA \\
\hline 94 & & Alburnus alburnus & USA \\
\hline 95 & & Alburnus chalcoides & \\
\hline 96 & & Coregonus albula & USA \\
\hline 97 & & Coregonus lavaretus & USA \\
\hline 98 & & Coregonus maraena & USA \\
\hline 99 & & Coregonus peled & USA \\
\hline 100 & & Gambusia holbrooki & Japan, Europe, Australia, USA \\
\hline 101 & & Ictalurus furcatus & USA, Japan \\
\hline 102 & & Pterygoplichthys disjunctivus & USA \\
\hline 103 & & Pterygoplichthys multiradiatus & \\
\hline 104 & & Rutilus rutilus & USA \\
\hline 105 & & Cyprinus carpio var. specularis & \\
\hline 106 & & Parachondrostoma toxostoma & Europe \\
\hline 107 & & Amphilophus citrinellus & USA \\
\hline 108 & & Clupeonella tscharchalensis & Europe \\
\hline 109 & & Cobitis bilineata & Europe \\
\hline 110 & & Knipowitschia longecaudata & Europe \\
\hline 111 & & Neogobius eurycephalus & Japan, Europe \\
\hline 112 & & Neogobius fluviatilis & Japan, Europe \\
\hline 113 & & Neogobius gorlap & Japan, Europe \\
\hline 114 & & Neogobius pallasi & Japan, Europe \\
\hline 115 & & Odontesthes bonariensis & USA \\
\hline 116 & & Siganus rivulatus & Europe \\
\hline 117 & Mollusca & Perna viridis & USA \\
\hline 118 & Arthropoda & Procambarus fallax & Japan, Europe, USA \\
\hline 119 & Amphibian & Osteopilus septentrionalis & Japan, USA \\
\hline 120 & & Xenopus laevis & Europe, UK, USA \\
\hline 121 & & Rana ridibundus & Europe, UK \\
\hline 122 & & Rana lessonae & \\
\hline 123 & & Bufo japonicus formosus & Japan \\
\hline 124 & & Bufo japonicus japonicus & Japan \\
\hline 125 & & Fejervarya kawamurai & \\
\hline 126 & & Fejervarya sakishimensis & \\
\hline 127 & & Rana japonica & \\
\hline 128 & & Pelophylax porosus & \\
\hline 129 & & Epidalea calamita & Japan \\
\hline 130 & & Sclerophrys mauritanica & \\
\hline 131 & & Rhinella marinus & IUCN, Japan, Europe, Australia, USA \\
\hline
\end{tabular}


Table 4 List of alert alien species in Republic of Korea (Continued)

\begin{tabular}{|c|c|c|c|}
\hline No. & Group & Scientific name & Listed in \\
\hline 132 & & Pelophylax esculentus & \\
\hline 133 & & Pelophylax kurtmuelleri & \\
\hline 134 & & Anaxyrus cognatus & Japan \\
\hline 135 & & Anaxyrus punctatus & Japan \\
\hline 136 & & Cryptobranchus alleganiensis & \\
\hline 137 & & Duttaphrynus melanostictus & Japan, USA \\
\hline 138 & & Rana grylio & Japan, China \\
\hline 139 & & Rana heckscheri & Japan, China \\
\hline 140 & & Rana pipiens & \\
\hline 141 & & Hylarana erythraea & \\
\hline 142 & & Hoplobatrachus tigerinus & \\
\hline 143 & & Hoplobatrachus rugulosus & \\
\hline 144 & & Litoria dentata & Australia \\
\hline 145 & & Litoria ewingii & New Zealand \\
\hline 146 & & Litoria raniformis & New Zealand \\
\hline 147 & Reptile & Boiga irregularis & IUCN, Japan, Europe, USA \\
\hline 148 & & Graptemys pseudogeographica & Europe, USA \\
\hline 149 & & Vipera aspis & \\
\hline 150 & & Mauremys mutica & Japan \\
\hline 151 & & Graptemys geographica & \\
\hline 152 & & Mauremys caspica & Japan \\
\hline 153 & & Pelomedusa subrufa & \\
\hline 154 & & Darevskia armeniaca & \\
\hline 155 & & Eutropis multifasciata & \\
\hline 156 & & Calotes mystaceus & USA \\
\hline 157 & & Calotes versicolor & USA \\
\hline 158 & & Protobothrops mucrosquamatus & Japan \\
\hline 159 & & Boiga cyanea & Japan \\
\hline 160 & & Rhabdophis subminiatus & \\
\hline 161 & & Boiga cynodon & Japan \\
\hline 162 & & Boiga nigriceps & Japan \\
\hline 163 & & Notechis scutatus & Australia \\
\hline 164 & & Epicrates maurus & USA \\
\hline 165 & & Ctenotus lancelini & Australia \\
\hline 166 & & Lampropholis delicata & New Zealand \\
\hline 167 & & Mauremys sinensis $\times$ Mauremys reevesii & Japan \\
\hline 168 & & Mauremys japonica $\times$ Mauremys reevesii & Japan \\
\hline 169 & Insect & Anoplolepis gracilipes & IUCN, New Zealand \\
\hline 170 & Spider & Atrax robustus & Japan \\
\hline 171 & & Latrodectus antheratus & Japan \\
\hline 172 & & Latrodectus apicalis & Japan \\
\hline 173 & & Latrodectus bishopi & Japan \\
\hline 174 & & Latrodectus cinctus & Japan \\
\hline 175 & & Latrodectus corallinus & Japan \\
\hline
\end{tabular}


Table 4 List of alert alien species in Republic of Korea (Continued)

\begin{tabular}{|c|c|c|c|}
\hline No. & Group & Scientific name & Listed in \\
\hline 176 & & Latrodectus curacaviensis & Japan \\
\hline 177 & & Latrodectus dahli & Japan \\
\hline 178 & & Latrodectus diaguita & Japan \\
\hline 179 & & Latrodectus elegans & Japan \\
\hline 180 & & Latrodectus erythromelas & Japan \\
\hline 181 & & Latrodectus geometricus & Japan \\
\hline 182 & & Latrodectus hasselti & Japan \\
\hline 183 & & Latrodectus hesperus & Japan \\
\hline 184 & & Latrodectus hystrix & Japan \\
\hline 185 & & Latrodectus indistinctus & Japan \\
\hline 186 & & Latrodectus karrooensis & Japan \\
\hline 187 & & Latrodectus katipo & Japan \\
\hline 188 & & Latrodectus lilianae & Japan \\
\hline 189 & & Latrodectus mactans & Japan \\
\hline 190 & & Latrodectus menavodi & Japan \\
\hline 191 & & Latrodectus mirabilis & Japan \\
\hline 192 & & Latrodectus obscurior & Japan \\
\hline 193 & & Latrodectus pallidus & Japan \\
\hline 194 & & Latrodectus quartus & Japan \\
\hline 195 & & Latrodectus renivulvatus & Japan \\
\hline 196 & & Latrodectus revivensis & Japan \\
\hline 197 & & Latrodectus rhodesiensis & Japan \\
\hline 198 & & Latrodectus thoracicus & Japan \\
\hline 199 & & Latrodectus tredecimguttatus & Japan \\
\hline 200 & & Latrodectus variegatus & Japan \\
\hline 201 & & Latrodectus & Japan \\
\hline 202 & Plant & Vincetoxicum rossicum & \\
\hline 203 & & Carduus acanthoides & USA \\
\hline 204 & & Carduus tenuiflorus & USA, Australia \\
\hline 205 & & Chromolaena odorata & IUCN, China, Europe, Australia, USA \\
\hline 206 & & Mikania micrantha & IUCN, Japan, Australia, China, USA \\
\hline 207 & & Senecio madagascariensis & Japan, USA, Australia \\
\hline 208 & & Sphagneticola trilobata & IUCN, USA, China \\
\hline 209 & & Cenchrus echinatus & China, Australia, USA \\
\hline 210 & & Neyraudia reynaudiana & USA \\
\hline 211 & & Brachiaria mutica & China \\
\hline 212 & & Vulpia bromoides & USA \\
\hline 213 & & Fallopia baldschuanica & USA, UK \\
\hline 214 & & Heracleum sosnowskyi & Europe \\
\hline 215 & & Hydrocotyle ranunculoides & Japan, Europe, UK, Australia \\
\hline 216 & & Asparagus asparagoides & USA, Australia, New Zealand \\
\hline 217 & & Landoltia punctata & USA \\
\hline 218 & & Elodea nuttallii & Europe, UK \\
\hline 219 & & Andropogon gayanus & Australia \\
\hline
\end{tabular}


Table 4 List of alert alien species in Republic of Korea (Continued)

\begin{tabular}{|c|c|c|c|}
\hline No. & Group & Scientific name & Listed in \\
\hline 220 & & Oenanthe pimpinelloides & Australia \\
\hline 221 & & Ageratina riparia & USA, Australia, New Zealand \\
\hline 222 & & Onopordum acanthium & USA \\
\hline 223 & & Bunias orientalis & Europe, USA \\
\hline 224 & & Alternanthera pungens & Japan, China, Australia \\
\hline 225 & & Prosopis glandulosa & IUCN, Europe \\
\hline 226 & & Salpichroa origanifolia & Australia \\
\hline 227 & & Myriophyllum heterophyllum & Japan, Europe, USA \\
\hline 228 & & Salvinia minima & USA \\
\hline 229 & & Sagittaria graminea & USA, Europe \\
\hline 230 & & Centaurea diffusa & USA \\
\hline 231 & & Ehrharta erecta & China, New Zealand, USA \\
\hline 232 & & Lolium persicum & China, Canada \\
\hline 233 & & Paspalum conjugatum & China, USA \\
\hline 234 & & Hydrocharis morsus-ranae & USA \\
\hline 235 & & Stratiotes aloides & USA, Australia \\
\hline 236 & & Eichhornia azurea & USA, Australia \\
\hline 237 & & Monochoria hastata & USA \\
\hline 238 & & Aegilops tauschii & China \\
\hline 239 & & Setaria palmifolia & New Zealand, USA \\
\hline 240 & & Echinocystis lobata & Europe, USA \\
\hline 241 & & Lycium ferocissimum & Australia, New Zealand, USA \\
\hline 242 & & Paspalum fimbriatum & China, USA \\
\hline 243 & & Berteroa incana & USA \\
\hline 244 & & Lepidium appelianum & \\
\hline 245 & & Heteropogon contortus & USA \\
\hline 246 & & Spartina densiflora & Japan, USA \\
\hline 247 & & Centaurea stoebe subsp. micranthos & Australia, USA \\
\hline 248 & & Rhaponticum repens & Australia, USA \\
\hline 249 & & Myriophyllum alterniflorum & Japan, USA \\
\hline 250 & & Passiflora foetida & China, USA \\
\hline 251 & & Spartina patens & Japan, USA \\
\hline 252 & & Acacia paradoxa & Australia, New Zealand, USA \\
\hline 253 & & Alhagi maurorum & Australia, USA, South Africa \\
\hline 254 & & Arctotheca calendula & New Zealand, USA \\
\hline 255 & & Asparagus scandens & Australia, New Zealand \\
\hline 256 & & Buddleja madagascariensis & New Zealand, USA, South Africa \\
\hline 257 & & Carpobrotus chilensis & New Zealand, USA \\
\hline 258 & & Cenchrus spinifex & Australia, USA \\
\hline 259 & & Crupina vulgaris & Australia, USA, Canada \\
\hline 260 & & Dolichandra unguis-cati & China, Europe, Australia, South Africa \\
\hline 261 & & Echium vulgare & USA, Australia, New Zealand \\
\hline 262 & & Ehrharta longiflora & New Zealand, USA \\
\hline 263 & & Erica lusitanica & Australia, New Zealand, Pacific islands \\
\hline
\end{tabular}


Table 4 List of alert alien species in Republic of Korea (Continued)

\begin{tabular}{|c|c|c|c|}
\hline No. & Group & Scientific name & Listed in \\
\hline 264 & & Erechtites valerianifolius & China, USA, Pacific islands \\
\hline 265 & & Euphorbia cyathophora & USA, Pacific islands \\
\hline 266 & & Flaveria bidentis & China, South Africa \\
\hline 267 & & Genista linifolia & Australia, USA \\
\hline 268 & & Genista monspessulana & Australia, USA, Pacific islands, Hawaii \\
\hline 269 & & Heliotropium europaeum & Australia, China \\
\hline 270 & & Hordeum bulbosum & \\
\hline 271 & & Hyptis brevipes & China, Australia \\
\hline 272 & & Hyptis suaveolens & China, Australia, Hawaii, Guam, Papua New Guinea, Philippines, Singapore, Taiwan \\
\hline 273 & & Ipomoea alba & USA \\
\hline 274 & & Iva axillaris & Australia, USA \\
\hline 275 & & Jatropha curcas & China, Australia \\
\hline 276 & & Lantana montevidensis & China, Australia, New Zealand, USA, Hawaii \\
\hline 277 & & Megathyrsus maximus & USA \\
\hline 278 & & Morella faya & Europe, Australia, Hawaii \\
\hline 279 & & Pittosporum undulatum & Australia, Europe, USA \\
\hline 280 & & Rosa bracteata & Europe, USA \\
\hline 281 & & Senecio angulatus & Japan, New Zealand \\
\hline 282 & & Toxicodendron radicans & Europe, Australia, USA \\
\hline 283 & & Acacia auriculiformis & USA, Singapore, Hawaii \\
\hline 284 & & Acacia confusa & \\
\hline 285 & & Acacia farnesiana & China \\
\hline 286 & & Acacia mearnsii & IUCN, New Zealand, South africa, Hawaii \\
\hline 287 & & Agropyron desertorum & \\
\hline 288 & & Ardisia elliptica & IUCN, Europe, Hawaii \\
\hline 289 & & Amelanchier spicata & Europe \\
\hline 290 & & Bassia hyssopifolia & \\
\hline 291 & & Bromus rubens & \\
\hline 292 & & Centaurea melitensis & \\
\hline 293 & & Chrysanthemoides monilifera & New Zealand \\
\hline 294 & & Cortaderia jubata & Europe, New Zealand, Hawaii, South africa \\
\hline 295 & & Cytisus striatus & \\
\hline 296 & & Delairea odorata & Australia \\
\hline 297 & & Dioscorea oppositifolia & \\
\hline 298 & & Dittrichia graveolens & Australia \\
\hline 299 & & Galeopsis tetrahit & Alaska \\
\hline 300 & & Emex spinosa & Australia, USA \\
\hline
\end{tabular}

\section{Abbreviations}

IAS: Invasive Alien Species; AAS: Alert Alien Species; IUCN: International Union for Conservation of Nature; IAS Act: Invasive Alien Species Act;

UAS: Uncategorized Alien Species; LORCA: Living Organisms Required to Have a Certificate Attached; GBNNSS: Great Britain Invasive Non-Native Species Strategy

\section{Acknowledgements}

Not applicable.

\section{Authors' contributions}

SHS and DEK designed the study and wrote the manuscript. SHS and ARJ performed data collect and analyzed the data. The authors read and approved the final manuscript.

\section{Funding}

This work was supported by a grant from the National Institute of Ecology (NIE-D-2019-09) and (NIE-A-2021-12) and funded by the Minis-try of Environment (MOE) of the Republic of Korea. 


\section{Availability of data and materials}

The datasets used and/or analyzed during the current study are available from the corresponding author on reasonable request.

\section{Declarations}

Ethics approval and consent to participate

Not applicable.

\section{Consent for publication}

Not applicable.

\section{Competing interests}

The authors declare that they have no competing interests.

Received: 16 September 2021 Accepted: 2 November 2021

Published online: 26 November 2021

\section{References}

Bomford M. Risk assessment models for establishment of exotic vertebrates in Australia and New Zealand. Canberra: Invasive Animals Cooperative Research Centre; 2008.

Brenton-Rule E, Frankel S, Lester P. Improving management of invasive species: new Zealand's approach to pre-and post-border pests. Policy Quarterly. 2016; 12(1):17-25.

Brummitt RK. World geographical scheme for recording plant distributions. 2nd ed; 2001. International Working Group on Taxonomic Databases for Plant Sciences (TDWG). Hunt Institute for Botanical Documentation, Carnegie Mellon University, Pittsburgh

Cal-IPC (California invasive plant council) (2006) California invasive plant inventory. Cal-IPC Publication 2006-02. California Invasive Plant Council: Berkeley, CA, USA

Congress, U. S. OTA. Harmful non-indigenous species in the United States. Washington DC: US Government Printing Office; 1993.

Department of Conservation (1996) Visitor strategy

European Commission (2014) Invasive alien species. http://ec.europa.eu/ environment/nature/invasivealien/. Accessed 23 Aug 2016

GB Non-Native Species Secretariat (2016) GB non-native species information portal. http://www.nonnativespecies.org/factsheet/index. Accessed 2 May 2016

Gederaas L, Moen TL, Skjelseth S, Larsen LK. Alien species in Norway - with the Norwegian Black List 2012. Norway: The Norwegian Biodiversity Information Centre; 2012.

IUCN. IUCN guidelines for the prevention of biodiversity loss caused by alien invasive species, IUCN-The World Conservation Union. Switzerland: Gland; 2000

Junior DPL, Magalhães ALB, Pelicice FM, Vitule JRS, Azevedo-Santos VM, Orsi ML, et al. Aquaculture expansion in Brazilian freshwaters against the Aichi Biodiversity Targets. Ambio. 2018;47(4):427-40.

Kettunen M, Genovesi P, Gollasch S, Pagad S, Starfinger U, ten Brink P, et al. Technical support to EU strategy on invasive species (IAS) - assessment of the impacts of IAS in Europe and the EU (final module report for the European Commission). Brussels, Belgium: Institute for European Environmental Policy (IEEP); 2008. p. 44. + Annexes

Kil JH, Kim CG. Overview of preventive measures against invasive alien species in Korea and suggestions for their improvement. Korean J Ecol Environ. 2014;47:239-46.

Kil JH, Mun S, Kim CG. Risk assessment tools for invasive alien species in Japan and Europe. Ecol Resilient Infrastructure. 2015;2(3):191-7.

Koh KS, Suh MH, Kil JH, Ku YB, Oh HK, Lee DG. Research on the effect of alien plants on ecosystem and their management (III). Incheon, Korea: National Institute of Environmental Research; 2002.

Luque GM, Bellard C, Bertelsmeier C, Bonnaud E, Genovesi P, Simberloff D, et al. The $100^{\text {th }}$ of the world's worst invasive alien species. Biological Invasions. 2014; 16:981-5.

McLeod R. Counting the cost: impact of invasive animals in Australia. Canberra: Cooperative Research Centre for Pest Animal Control; 2004.

Ministry for Primary Industries n.d. Unwanted organisms database. Wellington: Ministry of Agriculture and Forestry; 2016. Accessed 11 Jan 2016

Ministry of Environment (2014) Long-term management plan of alien species

Ministry of Environment notification. Designation and notification of alert species; 2017. p. 160.

Sardain A, Sardain E, Leung B. Global forecasts of shipping traffic and biological invasions to 2050. Nature Sustainability. 2019;2(4):274-82.
SCBD (Secretariat of the Covention on Biological Diversity) (2014) Global biodiversity outlook 4. Montréal, Canada

Sharp RL, Larson LR, Green GT. Factors influencing public preferences for invasive alien species management. Biol Conserv. 2011;144(8):2097-104.

US Department of Agriculture (2010) 'Federal noxious weed list', United States Department of Agriculture. Accessed 1 Oct 2015

Xu H, Qiang S, Genovesi P, Ding H, Wu J, Meng L, et al. An inventory of invasive alien species in China. NeoBiota. 2012;15:1-26.

\section{Publisher's Note}

Springer Nature remains neutral with regard to jurisdictional claims in published maps and institutional affiliations.
Ready to submit your research? Choose BMC and benefit from:

- fast, convenient online submission

- thorough peer review by experienced researchers in your field

- rapid publication on acceptance

- support for research data, including large and complex data types

- gold Open Access which fosters wider collaboration and increased citations

- maximum visibility for your research: over $100 \mathrm{M}$ website views per year

At BMC, research is always in progress.

Learn more biomedcentral.com/submissions 